\title{
Impact of Brand Equity on Television in Chennai City
}

\section{A. Rajalakshmi}

\begin{abstract}
Traditionally branding was seen as a mark of identification whereas now branding focuses on creating loyalty to the brand and helps in building long-lasting relationships with the customers. This empirical study highlights the impact of brand equity on television. Indian television market has numerous brands and the customers have the freedom to choose their brand according to their preferences and taste. Different brands provide different services, different outlooks and different prices. The customers have wide choice. The sample size of 120 who used television was analysed in order to determine the impact of brand equity. One sample t-test, bi-variate correlation and regression analysis was the tools used in the study. Findings in the study showed that relationship between brand equity and customer satisfaction was positive.
\end{abstract}

Keywords : Brand Equity, Customer satisfaction..

\section{INTRODUCTION}

B rands nowadays have become the valuable assets to the firm. The concept of branding was introduced in the early sixteenth century. In ancient days brands were used only for identification. Over the years the association of brand name with the product got strengthened. Branding was also used by customers to identify their products among the competitors and helped to develop an association with the product and feeling with their brands and made them loyal to their brands. They are enthusiastic even for paying additional amount for the products which has brand. Television is in no way exception to it. There are numerous brands like Samsung India Electronics, Sony India, Panasonic, Intex, Videocon, Micromax, BPL limited in the television market. At present television penetration is around $61 \%$ and there is scope for more growth and expansion. In the Asia Pacific Region, India is the second largest subscribers in the television market. It is expected that India will have vast growth and dominate the market till 2020 in the satellite television. It has become paramount importance for measuring the strategic value of brand equity as customers are constantly going behind the brands.

\section{REVIEW OF LITERATURE}

Arun Kumar.G (2014) made an analysis on the impact of brand equity of LG television on level of satisfaction of the users. Samples are collected from 115 respondents using convenient sampling in Mysore city. The result showed that

Revised Manuscript Received on December 05, 2019.

* Correspondence Author

Dr. A. Rajalakshmi*, Assistant Professor, Department of Commerce, Pachaiyappa's College, Chennai, India. Email: rajiramesh1711@gmail.com dimensions of brand equity had a significant association with customer satisfaction.

Kumaravel (2012) conducted a study on customer based brand equity on hypermarket store in India. Among the five dimensions of brand equity, perceived quality like superior technology, shop atmosphere and merchandise service etc., was efficient in building brand equity, as quality was more significant for the customers of hypermarket shop. The study also concluded that other determinants of brand like image, awareness, association and loyalty are not important for creating brand equity.

P.Natarajan (2011) in his paper highlights the results of dimensions of brand equity in Indian car industry where many competitors entered into the market. The result showed that brand loyalty plays important role in creating brand equity.

\section{STATEMENT OF THE PROBLEM}

The market has been carved up by a numbers of brands. Numerous brands were pushed into market in India. Indian consumers enjoy enormous freedom to choose their television brands from among the popular brands. However, the reason why customers stick to a particular brand in the midst of a wide range of choice remains to be studied in detail. The different brands provide different service, different product outlooks and different prices. Therefore, Indian consumers have a wide choice possibility when choosing a television. In contrast, how the television manufacturers attract customers to buy their products still lacks research, and it becomes an imperative to study it. So there is a necessity to understand the problem of the Indian marketing. This study proposes to analyse the impact of brand equity of television in Chennai city.

\section{OBJECTIVES OF THE STUDY}

The objectives of this study are as follows:

- To ascertain the satisfaction level of television users.

- To assess the impact of brand equity of television on satisfaction of the customer.

\section{HYPOTHESES}

- The perception level of customers towards Brand Equity of television does not differ with the mean score.

- There is no significant impact of brand equity of television on customers' satisfaction. 


\section{SCOPE OF THE STUDY}

The research aims to study the impact of brand equity of television on customer satisfaction in Chennai city, Tamil Nadu. The researcher selected responses from users of television in North Chennai, Central Chennai and South Chennai as the area of study.

\section{METHODOLOGY}

A structured questionnaire was used as research instrument to collect the primary data. Samples were collected from television users in Chennai city. 120 samples were collected using convenient sampling method. The following statistical tools were used for analysis.

- Percentage analysis method

- One sample t-test

- Simple Regression analysis

- Bi-variate correlation

\section{RESULTS AND DISCUSSION}

\section{A. Demographic Profile of the Respondents}

Demographic profiles of the respondents using television in Chennai city were analysed. Gender, age, education qualification, occupation, monthly family income and marital status of the respondents are presented in the Table 1.

Table 1: Demographic Profile of the Respondents

\begin{tabular}{|c|c|c|}
\hline $\begin{array}{l}\text { Demographic Profile } \\
\text { classification }(\mathrm{N}=120)\end{array}$ & $\begin{array}{l}\text { Number of } \\
\text { Respondent } \\
\text { s }\end{array}$ & $\begin{array}{c}\text { Percentag } \\
\text { e }\end{array}$ \\
\hline \multicolumn{3}{|l|}{ Gender } \\
\hline Male & 63 & 52.6 \\
\hline Female & 57 & 47.4 \\
\hline \multicolumn{3}{|l|}{ Age } \\
\hline Below 25 Years & 45 & 37.2 \\
\hline $25-35$ years & 48 & 39.9 \\
\hline $36-45$ years & 18 & 15.2 \\
\hline Above 45 years & 9 & 7.7 \\
\hline \multicolumn{3}{|l|}{ Education qualification } \\
\hline School level & 24 & 19.8 \\
\hline Diploma & 17 & 14.5 \\
\hline UG/PG & 59 & 49.5 \\
\hline Professional & 15 & 12.1 \\
\hline Others & 5 & 4.2 \\
\hline \multicolumn{3}{|l|}{ Occupation } \\
\hline Salaried Job & 40 & 33.6 \\
\hline $\begin{array}{l}\text { Business/Self-employe } \\
\text { d }\end{array}$ & 18 & 14.7 \\
\hline Professional & 19 & 15.9 \\
\hline Student & 26 & 21.5 \\
\hline Home maker & 10 & 8.4 \\
\hline Others & 7 & 5.9 \\
\hline Monthly family Income & & \\
\hline
\end{tabular}

\begin{tabular}{|c|c|c|}
\hline $\begin{array}{c}\text { Demographic Profile } \\
\text { classification }(\mathbf{N}=\mathbf{1 2 0})\end{array}$ & $\begin{array}{c}\text { Number of } \\
\text { Respondent } \\
\text { s }\end{array}$ & $\begin{array}{c}\text { Percentag } \\
\mathbf{e}\end{array}$ \\
\hline Less than Rs.50,000 & 85 & 70.5 \\
\hline Rs.50,000-1,00,000 & 21 & 17.8 \\
\hline Rs.1,00,001-2,00,000 & 8 & 6.8 \\
\hline Above Rs.2,00,000 & 6 & 4.9 \\
\hline Marital status & & \\
\hline Married & 47 & 39.5 \\
\hline Unmarried & 73 & 60.5 \\
\hline
\end{tabular}

It is inferred from the Table 1 that from the total 120 respondents, majority of the respondents are male $(52.6 \%$ of the respondents are male and $47.4 \%$ are female). It is found that $39.9 \%$ of the respondents are in the age group of 25-35 years and $49.5 \%$ of the respondents are UG/PG graduated. $33.6 \%$ of the respondents in the study are salaried employees and Majority of the respondents $(70.5 \%)$ have monthly income of less than Rs.50,000. Majority of the selected respondents are married.

\section{B. Television brands used by the respondents}

Television brands used by the respondents are exhibited in the Table 2 using percentage analysis.

Table 2: Television brands used by the respondents

\begin{tabular}{|c|c|c|}
\hline Television brands & $\begin{array}{c}\text { Number of } \\
\text { Customers }\end{array}$ & Percentage \\
\hline Sony & 28 & 23.4 \\
\hline Samsung & 42 & 34.8 \\
\hline LG & 31 & 25.9 \\
\hline Videocon & 8 & 7 \\
\hline Others & 11 & 8.9 \\
\hline Total & 120 & 100 \\
\hline
\end{tabular}

Table 2 exhibits respondent's preferred brands of Television. Samsung is the preferred brand for $34.8 \%$ of the selected respondents, $25.9 \%$ of the respondent's preferred the brand LG, another $23.4 \%$ of the respondents use Sony television, $8.9 \%$ of them preferred other brand television and only few respondents $(7 \%)$ are using the brand Videocon. It is observed that more respondents $(34.80 \%)$ prefer the brand Samsung television.

\section{Perception towards Brand equity}

Perception towards Brand equity among television users in Chennai city is studied. Five variables, namely, (i) I like to buy this brand among the competing brands with same features and quality, (ii) I have more satisfaction on this brand, (iii) I consider this brand as superior to other competing brands, (iv) The identity of this brand is strongly established in my mind and (v) 
This brand is more than a product to me were the five variables taken to understand the perception of the respondents. One sample t-test is used to test the significant difference of perception level among the respondents using television in Chennai city.

\section{H0: The perception level of respondents towards Brand equity does not differ.}

The results of one sample t-test for variables measuring the perception of respondents on Brand equity on television are shown in the Table 3.

Table 3: One sample t-test for Brand equity

\begin{tabular}{|l|c|c|c|}
\hline \multicolumn{1}{|c|}{ Statements } & $\begin{array}{c}\text { Mean } \\
(\mathrm{SD})\end{array}$ & $\mathrm{t}$-value & $\mathrm{p}$-value \\
\hline $\begin{array}{l}\text { I like to buy this brand } \\
\text { among the competing } \\
\text { brands with same features } \\
\text { and quality }\end{array}$ & $\begin{array}{c}2.64 \\
(0.825)\end{array}$ & $\begin{array}{c}1.386^{*} \\
*\end{array}$ & $<.001$ \\
\hline $\begin{array}{l}\text { I have more satisfaction on } \\
\text { this brand }\end{array}$ & $\begin{array}{c}1.36 \\
(0.231)\end{array}$ & $\begin{array}{c}6.270 * \\
*\end{array}$ & $<.001$ \\
\hline $\begin{array}{l}\text { I consider this brand is } \\
\text { superior to other competing } \\
\text { brands }\end{array}$ & $\begin{array}{c}2.73 \\
(1.026)\end{array}$ & $\begin{array}{c}3.890^{*} \\
*\end{array}$ & $<.001$ \\
\hline $\begin{array}{l}\text { The identity of this brand is } \\
\text { strongly established in my } \\
\text { mind }\end{array}$ & $\begin{array}{c}2.57 \\
(0.853)\end{array}$ & $\begin{array}{c}2.326^{*} \\
*\end{array}$ & $<.001$ \\
\hline $\begin{array}{l}\text { This brand is more than a } \\
\text { product to me }\end{array}$ & $\begin{array}{c}3.15 \\
(1.256)\end{array}$ & $\begin{array}{c}6.755^{*} \\
*\end{array}$ & $<.001$ \\
\hline
\end{tabular}

** Significant at $1 \%$ level

Table 3 highlights the respondent's opinion about Brand equity on television in Chennai city. It is noted from the table that all $\mathrm{p}$ values are less than 0.001. Therefore null hypothesis is rejected at $1 \%$ level of significance. This implies that there is a significant difference between responses given by the respondents towards Brand equity on television. Further the mean score of the variables; I like to buy this brand among the competing brand with same features and quality, (2.64), I consider this brand is superior to other competing brands (2.73), The identity of this brand is strongly established in my mind (2.57), This brand is more than a product to me (3.15) are high. The mean value of the variable: I have more satisfaction on this brand (1.36) is low. This shows that the respondent using television in Chennai city are having a good level of Brand equity. The respondents value the brand as superior one, the brand is identified as it is strongly established in their minds and they prefer the same brand even the other brands have the same features and quality.

\section{Relationship between Brand equity and Customer satisfaction on television.}

To test the significant relationship between Brand equity and Customer satisfaction on television among respondents using television in Chennai city, bi-variate correlation is used.
H0: There is no significant relationship between Brand equity and Customer satisfaction on television.

Table 4: Relationship between Brand equity and Customer satisfaction

\begin{tabular}{|c|c|c|}
\hline \multirow{2}{*}{} & \multicolumn{2}{|c|}{ Brand equity } \\
\cline { 2 - 3 } & r-value & p-value \\
\hline Customer satisfaction & $0.672 * *$ & $<.001$ \\
\hline
\end{tabular}

** Significant at $1 \%$ level

It is observed from the Table 4 that correlation between brand equity and customer satisfaction is positive $(\mathrm{r}=0.672)$. The null hypothesis is rejected at $1 \%$ level of significance. Therefore, there is significant correlation between brand equity and customer satisfaction of television users in Chennai city. It is also found that Brand equity enhances Customer satisfaction on television by $67.2 \%$.

\section{E. Impact of Brand equity on Customer Satisfaction of Television users}

Simple regression analysis was used to know the impact of brand equity on customer satisfaction. Brand equity of television is taken as dependent variable and customer satisfaction of television users in Chennai city as independent variable.

\section{H0: Brand equity does not have significant impact on customer satisfaction of television users.}

The result of regression analysis is presented in Table 5.

Table 5: Regression analysis for impact of Brand equity on customer satisfaction

\begin{tabular}{|c|c|c|c|c|}
\hline Variables & R2 & Beta & F-statistics & t- value \\
\hline \multirow{3}{*}{$\begin{array}{c}\text { Brand equity } \\
\text { Constant }\end{array}$} & 0.531 & & & \\
\cline { 2 - 2 } & Adjusted R2 & 0.186 & & \\
& 0.529 & 2.247 & $2.341^{* * *}$ & $\begin{array}{r}12.029 * * \\
27.141^{* * *}\end{array}$ \\
\cline { 2 - 2 } & & & \\
\hline
\end{tabular}

** Significant at $1 \%$ level

It is observed from the Table 5, the regression model's $\mathrm{F}$ value is 25.341 and it is significant at $1 \%$ level, therefore the null hypothesis is rejected. The coefficient of regression model (R2) is 0.531 (53.1\% of variability) which shows the good impact. One unit increase in Brand equity significantly has impact and improves Customer satisfaction on television by 0.186 units in Chennai city. The regression equation for impact of Brand equity on customer satisfaction is:

Customer satisfaction $=2.247+0.186$ (Brand equity)

Hence Brand equity has significant impact and improves Customer satisfaction on television in Chennai city. 


\section{SUGGESTIONS AND CONCLUSION}

From the study it is found that brand plays a major role to determine the marketability of the product. Television manufacturers should understand that brand causes high impact on the customer satisfaction. A well known brand can attract more customers. The study found that when the customers purchase the television they give more importance to the brand name. Therefore brand awareness should be created among the customers. This awareness can be emphasized by sales promotion and advertising. At the same time concentration on quality of product must be made. A product with good quality increases the repurchase attitude of the customers and they also recommend the product to others. As a result, their brand loyalty and brand preference will increase which ultimately raise the repurchase behavior especially in the case of products that stand away from customers. It is concluded that brand equity becomes the most important criterion in customers' purchasing television. The result of this study shows that the brand equity has more impact on customer satisfaction on television. This finding may assist retailers to better understand the factors influencing the customers' on television. By improving the standard of television one can improve the market. Ultimately it is the customer who is the real beneficiary when quality of products is increased.

\section{REFERENCES}

1. Aaker, D.A., \& Keller, K.L., (1990), Consumer evaluations of brand extensions, Journal of Marketing, 54, pp. 27-41.

2. Arun Kumar, G. (2014), "Brand Equity and Customer Satisfaction - A study of LG television in Mysore District", International Journal of Management Research and Review", vol.4, pp. 610-615.

3. Keller,K.L. and Lehman, D.R. (2006), "Brands and Branding: Research Findings and Future Priorities", Marketing Science, 25, 6, pp. 740-759.

4. Kotler Philip (2000), Marketing Management: the Millennium Edition, Upper Saddle River, Prentice Hall.

5. Kumaravel V, Kandasamy C. Measuring customer based brand equity on hypermarket store in India. European Journal of Social Sciences 2012; 28(3): 408-415.

6. Paramanand Dasar, Hundekar, S.G. and Mallikarjun Maradi (2013), "Consumer Behaviour on Consumer Durables with Reference to Bijapur District", Global Journal of Commerce and Management Perspective, vol. 2, No.1, pp.36-46

7. Rajarajan, M and Priyanga, T 92013), “ Consumer Behaviour Towards selected household Appliances in Ramanathapuram District”, Primax International Journal of Commerce and Management Research, Vol. 1, pp.1-10.

8. Vijayalakshmi, S and Mahalakshmi, V (2013), "An impact of consumer buying behavior in decision making process in purchase of electric home appliances in Chennai (India): an empirical study", Elixir Journal of Marketing Management, pp.15267-15273.

\section{AUTHOR PROFILE}

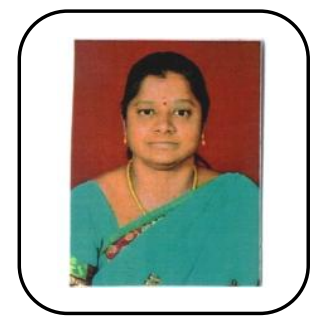

Dr.A.Rajalakshmi is currently working as an Assistant Professor at the Post Graduate Department of Commerce, Pachaiyappa's College, Chennai. She has 15 years of teaching experience at the Undergraduate level and 6 years at the Post Graduate level. She has specialization in the areas of finance and marketing. She has presented many papers at International and National Conferences and published 7 research articles. She holds Master's Degree in Commerce from the University of Madras. She obtained her M.Phil Degree from Alagappa University and Ph.D. from Madurai Kamaraj University. She has also produced 2 M.Phil Scholars. 